\title{
NORDIC JOURNAL OF
}

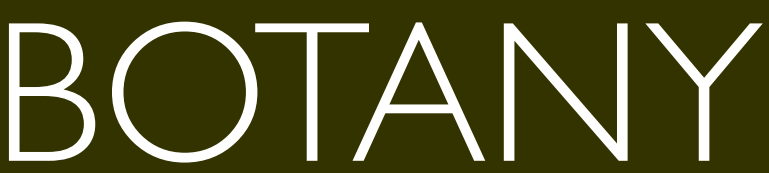

\section{Research}

\section{Studies on Homalomeneae (Araceae) of Borneo XXIII: a new rheophytic species of Homalomena (Punctulata Clade) from the Tau Range, Sarawak}

\author{
Sin Yeng Wong and Peter C. Boyce
}

S. Y. Wong (https://orcid.org/0000-0003-4042-9672), Inst. of Biodiversity and Environmental Conservation, Univ. Malaysia Sarawak, 94300 Kota Samarahan, Sarawak, Malaysia, and: Harvard Univ. Herbaria, Cambridge, MA, USA. - P. C. Boyce (https://orcid.org/0000-0002-5856-9561) $\square$ (phymatarum@gmail.com), Dept Biologie I, Systematische Botanik und Mykologie, Ludwig-Maximilians-Universität München, Menzinger Straße 67, DE-80638 München, Germany.

\section{Nordic Journal of Botany 2020: e02764 \\ doi: $10.1111 /$ njb.02764}

Subject Editor: John Parnell Editor-in-Chief: Torbjörn Tyler Accepted 14 April 2020 Published 22 June 2020

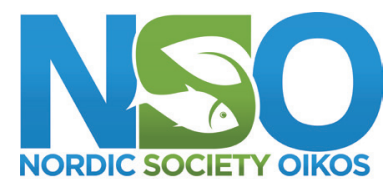

www.nordicjbotany.org
Homalomena cataractae is described and illustrated as a new species of Steenisian rheophyte belonging to the Homalomena punctulata-clade from the Tau range, Central Sarawak. A key to the species of the Homalomena punctulata-clade is provided.

Keywords: Araceae, Borneo, Homalomena, Punctulata Clade, rheophyte

\section{Introduction}

Homalomena is one of the largest genera of aroids occurring on Borneo, with 64 accepted species, and at least twice that number still to be described (Boyce and Croat 2020). The majority are terrestrial mesophytes, although a few are lithophytic (Wong and Boyce 2011), or helophytic (Wong et al. 2011). While some species occur habitually along riverbanks and on waterfalls (Ridley 1905, Kartini et al. 2015) no obligate rheophytes have been described for Borneo.

A molecular phylogeny of Asian Homalomena (Wong et al. 2013) resolved four main clades - Homalomena, Chamaecladon, Cyrtocladon and Punctulata, informally referred to as supergroups - all of which occur on Borneo, with Punctulata endemic to the island. The clades are well supported on characteristics of the blooms and florets. The spathe in Homalomena and Chamaecladon lacks a constriction, and both clades have pistillate florets consisting of an ovary and a staminode. In Chamaecladon the staminode is much shorter than the pistil, whereas in Homalomena the staminode equals the pistil. Staminate florets have two stamens in Chamaecladon and four in Homalomena.

Species of Cyrtocladon and Punctulata have constricted spathes and staminate florets each with four to six stamens and which in Cyrtocladon secrete conspicuous resin droplets between the florets (Hoe et al. 2016), while the leaf blades have well-developed posterior lobes. By contrast, species of Punctulata do not produce resin from between the staminate florets and the leaf blades lack posterior lobes, usually being decurrent on the petiole, or at most with broadly rounded bases. Two of the three subclades of the Punctulata clade (the Insignis-complex and Punctulata-complex) lack staminodes

(C) 2020 Nordic Society Oikos. Published by John Wiley \& Sons Ltd 